\title{
Red Cell Volume Distribution Width to Platelet Ratio is an Important Predictor of Liver Fibrosis and Cirrhosis in Chronic Hepatitis B
}

\author{
Eritrosit Dağılım Genișliği Trombosit Oranı Kronik Hepatit B'de Karaciğer Fibrozisi ve Sirozun \\ Önemli Bir Belirleyicisidir
}

\author{
Ismail Necati HAKYEMEZ, Sibel BOLUKÇU, Bülent DURDU, Turan ASLAN
}

Bezmialem Vakif University Faculty of Medicine, Department of Infectious Diseases and Clinical Microbiology, Istanbul, Turkey

\begin{abstract}
Objective: In recent years, a lot of non-invasive tests have been examined for estimating the severity of liver fibrosis in patients with chronic hepatitis B (CHB). We aimed to evaluate the role of simple and valuable platelet-derived indices in estimating the stage of fibrosis and cirrhosis in patients with CHB.

Materials and Methods: A total of 434 biopsy-proven naive CHB patients were included in the study. Liver biopsy samples were examined using the ISHAK scoring system. Age, sex, complete blood count parameters and the stage of fibrosis of the patients were recorded. The patients were evaluated according to the severity of fibrosis (stage 0-2: No fibrosis/mild fibrosis and stage 3-6: Significant fibrosis) and the presence of cirrhosis (stage 0-4: No cirrhosis, stage 5-6: Cirrhosis).

Results: Of the 434 patients included in the study, 252 (58.1\%) were men and $182(41.9 \%)$ were women. The mean age of the patients was $42.7 \pm 12.2$ years. Significant liver fibrosis was found in 108 (24.9\%) patients and cirrhosis in 43 (9.9\%) patients. In dual analysis, alterations in many platelet-derived parameters were observed. Receiver operating characteristic curve analysis revealed that red blood cell distribution width to platelet ratio index was the highest area under the curve value (0.777) in predicting significant liver fibrosis and the cutoff value was 0.0814 , sensitivity was $56 \%$ and specificity was $87 \%$.

Conclusion: Platelet-derived indices may play an important role in observing the progression of liver fibrosis and cirrhosis. Platelet ratio index is significantly increased in advanced liver fibrosis in patients with CHB, and can be defined as independent predicting factor in liver fibrosis.

Keywords: Chronic hepatitis B, platelet-derived indices, liver fibrosis, cirrhosis
\end{abstract}

ÖZ

Amaç: Son yllarda, kronik hepatit B (KHB) hastalarında fibrozis şiddetini tahmin etmek için bir çok non-invaziv test çalışılmışıı. Biz basit ve kullanışlı olan platelet kökenli indekslerin kronik hepatit B (KHB) hastalarında fibrozis düzeyi ve siroza gidişte rolünü araştırmayı amaçladık.

Gereç ve Yöntemler: Çalışmaya biyopsi ile kanıtlanmış 434 naif KHB hastası dahil edildi. Karaciğer biyopsi örnekleri ISHAK skorlama sistemi kullanılarak incelendi. Yaş, cinsiyet, tam kan sayım parametreleri ve fibrozis evresine ait hasta verileri kaydedilmiştir. Hastalar, fibrozis şiddeti (evre 0-2: Fibrozis yok/hafif ve evre 3-6: Önemli fibrozis) ve siroz varlı̆ıı (evre 0-4: Siroz yok, evre 5-6: Siroz) açısından değerlendirilmiştir.

Bulgular: Çalışmaya dahil edilen 434 hastanın, 252'si $(\% 58,1)$ erkek, 182'si $(\% 41,9)$ kadındı. Hastaların yaş ortalaması $42,7 \pm 12,2$ idi. Hastaların 108 'inde $(\% 24,9)$ önemli karaciğer fibrozisi, 43'ünde $(\% 9,9)$ siroz saptandı. Ikili analizlerde platelet temelli birçok parametrede anlamlı değişkenlikler saptanmıştır. Alııı işletim karakteristiği analizi ile yaptığımız değerlendirmede eritrosit dağılım genişliği/ trombosit indeksini önemli karaciğer fibrozisini öngörmede en yüksek eğri altında kalan alan değeri $(0,777)$ olarak saptadık ve cutoff değerini 0,0814 , duyarlıı̆ıı \% $\%$, özgüllüğü \%87 olarak belirledik.

Sonuç: Platelet kökenli indeksler, karaciğer fibrozisi ve siroza ilerlemeyi gözlemlemede önemli bir rol oynayabilir. Trombosit indeksi, KHB hastalarının ilerlemiş karaciğer fibrozisinde anlamlı olarak daha yüksektir ve karaciğer fibrozisinin bağımsız belirleyen faktörü olarak tanımlanabilir.

Anahtar Kelimeler: Kronik hepatit B, trombosit kökenli indeksler, karaciğer fibrozisi, siroz

Hakyemez IN, Bolukçu S, Durdu B, Aslan T. Red Cell Volume Distribution Width to Platelet Ratio is an Important Predictor of Liver Fibrosis and Cirrhosis in Chronic Hepatitis B. Viral Hepat J 2016;22:52-57 


\section{Introduction}

Hepatic fibrosis is a part of structural and functional changes observed in chronic liver disease (CLD). In the past 25 years, studies have revealed numerous cellular and molecular mechanisms leading to hepatic fibrogenesis. From the biological perspective, fibrogenesis is a dynamic process characterized by accumulation of fibrillar extracellular matrix as a consequence of continuous derangement and remodeling related to chronic tissue damage (1). The stage of fibrosis is among the most significant prognostic factors in CLD regarding development of cirrhosis and liver-related complications. Liver biopsy has been traditionally considered as the gold standard in assessment of liver fibrosis tissue damage in patients with CLD. Along with technical problems, such as length of biopsy material, problems about experience of the doctor obtaining biopsy samples and pathologist assessing the sample and risk of potential life-threatening complications limit the use of invasive procedures (2,3). Preferring non-invasive, cost-effective and simple methods while evaluating severity of liver fibrosis may be a more rational choice due to the above mentioned reasons. In recent years, for the evaluation of CLD severity, several non-invasive markers have been developed as an alternative to liver biopsy (4). However, the methods used were rather based on studies about chronic hepatitis $\mathrm{C}(\mathrm{CHC})$ (5). In the literature, inconsistent conclusions were reached in estimating states of liver fibrosis in $\mathrm{CHB}$ patients. Recently, various models were proposed for $\mathrm{CHB}$ patients, however, to use these models in daily practice seems difficult because they are rarely used biological markers or require specific software programs to make some calculations (6). Thus, there is an unmet need for reliable, simple and routine methods predicting liver fibrosis (7).

Hematological complete blood count (CBC) parameters are the most utilized laboratory tests in clinical practice. CBC includes parameters, such as white blood cell (WBC), red blood cell (RBC) and platelet (PLT) as well as some morphological indices. PLT has a primary role in liver inflammation mechanisms. It has a positive role in liver regeneration, but may have negative effect on the liver by causing immune-mediated injury (8). There is a negative correlation between progression of liver fibrosis and PLTs (7). In numerous studies, effectiveness of these parameters and indices on predicting outcome of the disease and risk of mortality was investigated $(9,10,11,12)$.

In recent years, several studies employing platelet-derived indices (PDIs) in order to predict fibrosis level in CHB patients were carried out with inconsistent results and both number of cases and investigated parameters were limited. In this study, we aimed to determine effectiveness of simple and easily available complete blood parameters and PDI in CHB patients in predicting significant fibrosis and cirrhosis.

\section{Materials and Methods}

\section{Study Population}

This was a retrospective case-control study evaluating chronic hepatitis B virus (HBV)-infected cases. The study included 434 naive $\mathrm{CHB}$ patients followed up after diagnosis and treatment in Department of Infectious Diseases and Clinical Microbiology, Bezmialem Vakıf University Faculty of Medicine, Istanbul, Turkey between January 2011 and December 2015. Patients, aged 18 years and older, having hepatitis B surface antigen positivity for more than six months, liver biopsy evaluated by using ISHAK scoring system, having estimable CBC parameters before biopsy and treatment were included in this study. Patients having coinfection of hepatitis $\mathrm{C}$ virus $(\mathrm{HCV})$, human immunodeficiency virus and hepatitis D virus, autoimmune disorders, metabolic liver disease, cardiac diseases, atherosclerotic diseases, hypertension, vascular diseases, chronic pulmonary diseases, renal diseases, chronic infections, diabetes mellitus, rheumatic diseases, splenectomy, hematological diseases, malignancy, pregnancy, taking drugs such as antidiabetics, hyperlipidemics, antihypertensives, warfarin, heparin, and aspirin were excluded from this study. The patients were evaluated according to severity of fibrosis (stage 0-2: No/mild fibrosis, stage 3-6: Significant fibrosis) and presence of cirrhosis (stage 0-4: No cirrhosis, stage 5-6: Cirrhosis). Case-control groups were also constructed according to the stage of liver fibrosis. Case groups were described as patients having advanced stages of fibrosis (stage 3-6 and stage 5-6). Control groups were described as patients having stage $0-2$ and stage $0-4$ scores.

\section{Laboratory Analysis}

Pre-treatment serum HBV-DNA was measured by using realtime polymerase chain reaction method (BioRad iCycler iQ System, Qiagen DNA isolation kit, Hilden, Germany: Detection limit: 20 IU/ $\mathrm{mL}$ ). CBC analysis was done by Advia 2120 (Siemens Healthcare Diagnostics, Siemens, Dublin, Ireland, Advia CDC Timepac CN free No. T01-3627-01) full automated hematological analyzer. All blood samples were analyzed within an hour. WBC, neutrophil (NEU), lymphocyte (LYM), RBC, mean corpuscular volume (MCV), hemoglobin, red blood cell distribution width (RDW), PLT, mean PLT volume (MPV), PLT distribution width (PDW), plateletcrit (PCT) along with estimated PLT-derived indices RPR, mean platelet volume to platelet ratio (MPR), PLT to WBC ratio (PWR), NEU to PLT ratio (NPR), and PLT to LYM ratio (PLR) were included in the evaluation.

\section{Histological Evaluation}

Ultrasound-guided liver biopsy was obtained by fully automated biopsy needle from at least five portal ducts as minimum $1.5 \mathrm{~cm}$ liver tissue for diagnosis. The samples were prepared by using hematoxylin-eosin and Masson's trichrome stains on formalin-fixed paraffin-embedded liver tissue. Liver biopsy was performed in all patients and biopsy samples were examined using the ISHAK scoring system.

\section{Statistical Analysis}

Statistical analysis was performed using Statistical Package for Social Sciences (SPSS) software (version 17, SPSS, Inc., Chicago, IL, USA). Conformity of continuous variables to normal distribution was evaluated by the single-sample Kolmogorov-Smirnov test. Categorical variables were expressed as percentage and number and in comparison of means, the independent-sample t-test, Mann-Whitney $U$ test, and the Kruskal-Wallis $H$ test were used as appropriate by considering conformity to normal distribution and number of evaluable subjects. Binary logistic regression analysis was performed using block entry approach to examine the contribution of variables in identifying the cases with severe fibrosis. Receiver operating characteristic (ROC) curve analysis was performed to determine the optimal cut-off value for the variables 
included in the model. The optimal cut-off values were identified by calculating the Youden index (13). All p-values were 2-sided, and values 0.05 were considered statistically significant.

\section{Results}

\section{Patients' Characteristics}

Nine hundred thirty-eight patients of the 1372 patients were excluded from the study as per exclusion criteria. 252 (58.1\%; mean age: $42.7 \pm 12.2$ years) of 434 subjects included in the study were male and 182 (41.9\%) were female. Hepatitis B e antigen was positive in $70(16.1 \%)$ patients. One hundred and eight (24.9\%) patients had significant fibrosis (stage 3-6) and 43 (9.9\%) had cirrhosis (F5-6).

\section{Predictors of Liver Fibrosis}

The relationship between significant liver fibrosis and cirrhosis and $\mathrm{CBC}$ parameters and PDI is shown in Table 1. WBC, NEU, LYM, RBC, PLT, PCT values were lower in significant fibrosis and presence of cirrhosis $(p<0.05)$. Higher MCV was found to be associated with cirrhosis $(p=0.004)$, but no correlation with significant fibrosis was found $(p=0.106)$. Hemoglobin was not associated with significant fibrosis and cirrhosis. Advanced regression analysis revealed no association between PDW value and significant fibrosis ( $p=0.67)$. PLR among PDI was significantly lower in significant fibrosis $(p=0.003)$, but there was no relationship between PDW value and presence of cirrhosis $(p=0.329)$. With significant fibrosis and presence of cirrhosis, RPR, MPR, NPR indices were higher and PWR was lower and the relationship was statistically significant $(p=0.001)$.

In logistic regression analysis, the association between RDW, PLT, MPV values and significant liver fibrosis was statistically significant in CHB patients (Table 2).

Evaluations performed by using $\mathrm{ROC}$ analysis revealed that RPR index is more valuable in predicting liver fibrosis (Table 3, Figure 1).

\section{Discussion}

The aim of this study was to find out the most valuable PDI predictive of significant fibrosis and cirrhosis to evaluate its effectiveness and develop an appropriate method by using simple, cost effective and easily available CBC tests. In our study, RPR was found to be more valuable in predicting advanced liver fibrosis compared to other PDls. The mechanism underlying between RDW and liver fibrosis is not fully understood yet. Increase in RDW may be an indicator of iron immobilization and inflammatory stress (14). Excessive iron load and inflammation may subsequently contribute to liver fibrosis. The role of PLTs in progression of fibrosis is also not clear. However, it has been shown that in a negative correlation with PLTs, decrease in profibrogenic transforming growth factor-beta expression and increase in matrix metalloproteinase expression may alleviate liver fibrosis (15). RDW increase may be observed in CLDs and particularly in cirrhosis as a result of hemolytic anemia which is common in these conditions

\begin{tabular}{|c|c|c|c|c|c|c|}
\hline \multirow[b]{2}{*}{ Parameters } & \multicolumn{3}{|l|}{ Severity of fibrosis } & \multicolumn{3}{|c|}{ Presence of cirrhosis } \\
\hline & $\begin{array}{l}\text { No/mild fibrosis } \\
n=326(75.1 \%)\end{array}$ & $\begin{array}{l}\text { Significant fibrosis } \\
\mathrm{n}=108(24.9 \%)\end{array}$ & $p$ value & $\begin{array}{l}\text { Non-cirrhosis } \\
\mathrm{n}=391(90.1 \%)\end{array}$ & $\begin{array}{l}\text { Cirrhosis } \\
n=43(9.9 \%)\end{array}$ & $p$ value \\
\hline Age (years) & $40.73 \pm 11.56$ & $48.54 \pm 12.3$ & 0.001 & $41.60 \pm 11.89$ & $52.47 \pm 10.72$ & 0.001 \\
\hline Gender (male) & $182 / 326(56)$ & $70 / 108(65)$ & 0.10 & $218 / 391(\% 56)$ & $34 / 43(\% 79)$ & 0.003 \\
\hline WBC $\left(103 / \mathrm{mm}^{3}\right)$ & $6950 \pm 1513$ & $6298 \pm 1696$ & 0.001 & $6910.38 \pm 1487$ & $5672.09 \pm 1975$ & 0.001 \\
\hline $\operatorname{NEU}\left(103 / \mathrm{mm}^{3}\right)$ & $3853 \pm 1176$ & $3537 \pm 1248$ & 0.018 & $3822.77 \pm 1152$ & $3334.65 \pm 1522$ & 0.011 \\
\hline LYM (103/mm³) & $2334 \pm 630$ & $1999 \pm 700$ & 0.001 & $2322.49 \pm 627$ & $1602.32 \pm 642$ & 0.001 \\
\hline $\mathrm{RBC}\left(106 / \mathrm{mm}^{3}\right)$ & $4.99 \pm 0.46$ & $4.80 \pm 0.56$ & 0.001 & $4.97 \pm 0.46$ & $4.62 \pm 0.66$ & 0.001 \\
\hline $\operatorname{MCV}(f L)$ & $86.21 \pm 4.73$ & $87.25 \pm 6.09$ & 0.106 & $86.23 \pm 5.04$ & $88.62 \pm 5.30$ & 0.004 \\
\hline $\mathrm{Hb}(\mathrm{g} / \mathrm{dL})$ & $14.34 \pm 1.6$ & $14.01 \pm 1.8$ & 0.669 & $14.31 \pm 1.57$ & $13.77 \pm 2.12$ & 0.684 \\
\hline PLT $\left(103 / \mathrm{mm}^{3}\right)$ & $226.53 \pm 59$ & $167.69 \pm 63$ & 0.001 & $220.07 \pm 59.68$ & $137.47 \pm 65.53$ & 0.001 \\
\hline MPV (fL) & $10.50 \pm 1.11$ & $10.57 \pm 1.25$ & 0.590 & $10.51 \pm 1.14$ & $10.63 \pm 1.21$ & 0.484 \\
\hline PDW (\%) & $13.44 \pm 2.55$ & $14.44 \pm 2.93$ & 0.001 & $13.60 \pm 2.62$ & $14.44 \pm 3.09$ & 0.053 \\
\hline РСТ (\%) & $0.24 \pm 0.06$ & $0.19 \pm 0.09$ & 0.001 & $0.23 \pm 0.06$ & $0.17 \pm 0.12$ & 0.001 \\
\hline RDW (\%) & $13.48 \pm 1.25$ & $14.11 \pm 1.48$ & 0.001 & $13.55 \pm 1.30$ & $14.42 \pm 1.41$ & 0.001 \\
\hline RPR & $0.06 \pm 0.018$ & $0.10 \pm 0.05$ & 0.001 & $0.066 \pm 0.02$ & $0.13 \pm 0.064$ & 0.001 \\
\hline MPR & $0.05 \pm 0.017$ & $0.075 \pm 0.041$ & 0.001 & $0.052 \pm 0.018$ & $0.097 \pm 0.053$ & 0.001 \\
\hline PWR & $0.0336 \pm 0.01$ & $0.0272 \pm 0.01$ & 0.001 & $0.033 \pm 0.01$ & $0.025 \pm 0.01$ & 0.001 \\
\hline NPR & $17.72 \pm 6.01$ & $22.97 \pm 9.32$ & 0.001 & $18.20 \pm 6.22$ & $26.59 \pm 11.38$ & 0.001 \\
\hline PLR & $0.104 \pm 0.04$ & $0.09 \pm 0.04$ & 0.003 & $0.10 \pm 0.04$ & $0.095 \pm 0.05$ & 0.329 \\
\hline \multicolumn{7}{|c|}{$\begin{array}{l}\text { Gender values are case count (\%). Other all values are mean } \pm \text { SD (standard deviation). WBC: white blood cell; NEU: Neutrophil, LYM: Lymphocyte, RBC: Red blood } \\
\text { cell, MCV: Mean corpuscular volume, Hb: Hemoglobin, PLT: Platelet, MPV: Mean platelet volume, PDW: Platelet distribution width, PCT: Plateletcrit, RDW: Red blood } \\
\text { cell distribution width, RPR: Red blood cell distribution width to platelet ratio, MPR: Mean platelet volume to platelet ratio, PWR: Platelet to white blood cell ratio, } \\
\text { NPR: Neutrophil to platelet ratio, PLR: Platelet to lymphocyte ratio }\end{array}$} \\
\hline
\end{tabular}


(16). In some studies, increasing RDW level was found to be associated with severity of disease in CHB patients $(10,17)$. When there was a $1 \%$ increase in RDW level, risk of progressive liver fibrosis has increased by $12.1 \%$. However, the mechanism which increases RDW level in higher stage of liver fibrosis is still not clear (18). We have determined that RDW is a significant variable in predicting advanced liver fibrosis by performing dual analysis and multivariate analysis. PLTs have a critical role in maintaining homeostasis, but are also important mediators of acute and chronic inflammatory diseases particularly following liver injury. PLTs play an important role in HBV-associated acute and chronic liver diseases by increasing accumulation of virus-specific CD8+ $\mathrm{T}$ cells and nonspecific inflammatory cells in liver parenchyma (19). Thrombocytopenia is a known complication of CLD and cirrhosis. PLT is used in various predictive models of liver fibrosis and cirrhosis. In a meta-analysis, it has been shown that aspartate aminotransferase (AST)-PLT ratio index (APRI) and fibrosis-4 (FIB-4) index can identify liver fibrosis in $\mathrm{CHB}$ with a moderate sensitivity and accuracy (20). Chen et al. (7) are the first investigators reporting an association between RDW and liver fibrosis and have reported that in the study, the most robust predictors in $\mathrm{CHB}$ patients namely RDW and PLT when used to get RPR have led to more accurate prediction of the risk of significant fibrosis (63.1\%) and cirrhosis (73.7\%) compared to AST-alanine aminotransferase (ALT) ratio (AAR), FIB-4 and APRI. Cengiz and Ozenirler (21) have determined RPR index as an independent predictor of significant and advanced liver fibrosis in 54 patients with non-alcoholic fatty liver disease (NAFLD). In a recently published study including 482 patients with chronic hepatitis B by Lee et al. (22), it was stated that when transient elastography is not available RPR index may serve as a simple method lowering the need for liver biopsy. In our study, the evaluation by using ROC analysis has revealed that RPR index had the highest area under the curve value $(0.777)$ in

Tablo 2. Comparison of variables associated with the presence of significant fibrosis (stage 3-6)

\begin{tabular}{|l|l|l|l|l|}
\hline Variables & Beta value & Odds ratio & $\begin{array}{l}\text { 95\% confidence } \\
\text { interval }\end{array}$ & p value \\
\hline RDW & 0.353 & 1.423 & $1.164-1.738$ & 0.001 \\
\hline PLT & -0.055 & 0.946 & $0.907-0.987$ & 0.01 \\
\hline MPV & -0.803 & 0.448 & $0.215-0.933$ & 0.03 \\
\hline PDW & -0.023 & 0.978 & $0.880-1.085$ & 0.67 \\
\hline $\begin{array}{l}\text { RDW: Red blood cell distribution width, PLT: Platelet, MPV: Mean platelet } \\
\text { volume, PDW: Platelet distribution width }\end{array}$ \\
\hline
\end{tabular}

predicting significant liver fibrosis with a cut off value of 0.0814 , and its sensitivity was $56 \%$ and specificity was $87 \%$. This result was consistent with other studies performed to predict severe liver fibrosis in $\mathrm{CHB}$ and $\mathrm{CHC}$ patients $(7,23)$.

MPV and PDW are parameters measured in routine blood counts reflecting the size and the degree of difference in size of PLTs. In destructive thrombocytopenia, higher MPV levels and in hypoproliferative thrombocytopenia, lower MPV levels are observed (24). In CHB patients, IL-6 increasing with inflammation increases PLT production in bone marrow (25). High MPV levels are associated with cardiovascular diseases, cerebrovascular diseases and certain risk factors, such as mild inflammatory conditions predisposing to thrombosis (26). PDW which is a more specific marker for PLT activation may be used in differential diagnosis of PLT disorders. In a study, a positive correlation between high PDW and MPV levels and severity of vascular injury was shown (27). MPV and MPR may be used in sepsis and systemic inflammatory response syndrome studies (28). MPV was also investigated in liver diseases such as steatosis, cirrhosis and hepatitis (29). Cho et al. (30) have found in their study including 165 hepatocellular carcinoma (HCC) patients that MPR index was more relevant than MPV as an indicator of tumor presence. Karagoz et al. (10) have established MPV and RDW values as independent risk factors in predicting liver fibrosis in $\mathrm{CHB}$, however, they found that PDW was not statistically significant. In our study, we also have determined significant association between MPV and MPR and prediction of severe fibrosis in CHB patients. PLR index has a significant role in predicting outcome of hepatocellular cancer. Lai et al. (31) has determined in $181 \mathrm{HCC}$ patients that PLR was a good determinant of recurrence risk after liver transplantation. In our study, lower PLR index was significantly associated with fibrosis but no association was found with cirrhosis. Studies about NPR and PWR indices are very scarce in the literature. Menezes et al. (32) have reported that a PWR index of $<8$ during presentation in sepsis patients was associated with higher mortality in day 4 and day 28. In our study, PWR index was significantly lower in patients at cirrhosis stage. De Ferrari et al. (33) have determined that higher NPR index was independent determinant of shortterm or long-term mortality in patients with myocardial infarction. In our study, NPR was found to be higher in CHB patients with advanced fibrosis. Value of PCT which is a marker of PLT activation has a tendency to increase particularly in cardiovascular diseases; it is calculated by using PCT $=\mathrm{PLT}$ count $\times \mathrm{MPV} / 10^{7}$ formula (34). Tsai et al. (35) has concluded that lower PCT value in $144 \mathrm{HCV}$ patients as compared to control group was a

\begin{tabular}{|c|c|c|c|c|c|c|c|c|}
\hline Indices & AUC & Cutoff & $95 \% \mathrm{Cl}$ & $p$ value & Sensitivity & Specificity & PPV & NPV \\
\hline RPR & 0.777 & 0.0814 & $0.723-0.831$ & 0.001 & 0.56 & 0.87 & 58.7 & 85.8 \\
\hline MPR & 0.735 & 0.0575 & 0.677-0.792 & 0.001 & 0.63 & 0.74 & 44.5 & 85.8 \\
\hline PWR & 0.697 & 0.0272 & $0.637-0.758$ & 0.001 & 0.58 & 0.77 & 45.3 & 84.7 \\
\hline NPR & 0.673 & 21.1337 & $0.612-0.733$ & 0.001 & 0.53 & 0.77 & 43.2 & 83.1 \\
\hline PLR & 0.621 & 0.0632 & $0.558-0.684$ & 0.001 & 0.29 & 0.91 & 52.5 & 79.4 \\
\hline
\end{tabular}


significant finding. Also in our study, lower PCT value in CHB patients with advanced liver fibrosis was considered statistically significant. Studies about PCT values are scarce and we assume that more detailed and comprehensive studies are needed.

\section{Study Limitations}

There are some limitations in this study. First, we have not investigated other etiologic factors increasing RDW levels such iron or vitamin B12 deficiency. Secondly, we could not investigate possible variation due to genotype, because in our country genotype testing for $\mathrm{CHB}$ patients is not a routine practice. Thirdly, age-platelet index, gamma-glutamyl transpeptidase (GGT) to platelet ratio, platelet-age-phosphatase-alpha-fetoproteinAST index, Goteburg University Cirrhosis Index, platelet-spleen diameter ratio, AST-platelet-GGT-alpha-fetoprotein index, Forn's index, AAR, APRI, FIB-4, fibro-quotient and other PDls were not used in this study. Fourthly, time regarding laboratory results could not be standardized, because we accepted the most recent laboratory results obtained before the biopsy without stating a time interval. Fifthly, the size of the sample was limited because it was a single-center study. Sixthly, specificity of RPR index is high but its sensitivity is lower. Due to these reasons, we think that more comprehensive multi-centered studies about prediction of fibrosis in CHB patients including comparison of these PDIs and other noninvasive methods are warranted.

\section{Conclusion}

Our study helped us obtaining significant information about the use of $\mathrm{CBC}$ in prediction of $\mathrm{CHB}$ prognosis. Along with RDW and platelet count being cost-effective, easily calculable RPR index was determined as having the most effective predictive value. This information may help us reducing the number of irrelevant liver biopsy.

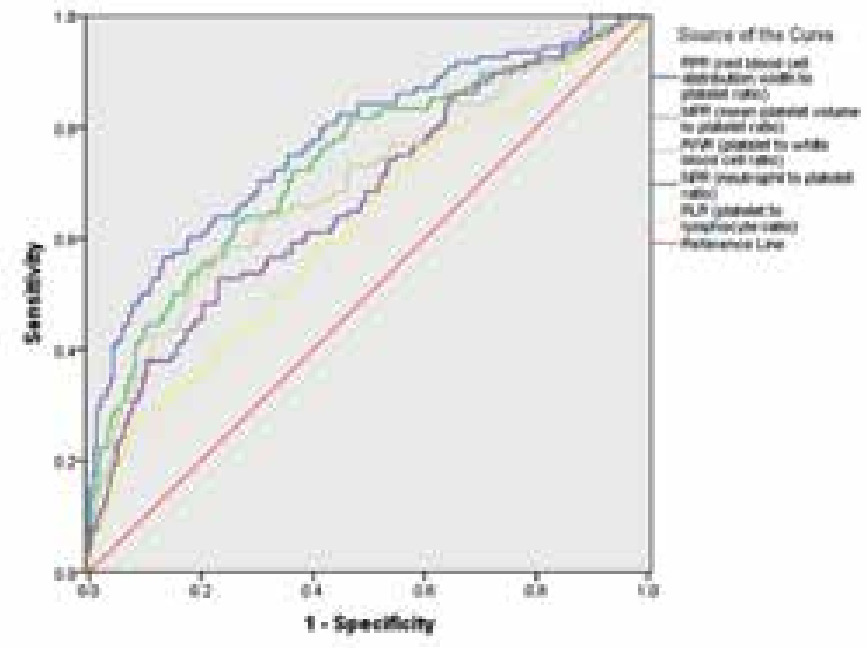

Figure 1. Receiver operating characteristic curves of plateletderived indices in predicting significant fibrosis (stage 3-6) at optimum cut-off point

RPR: Red blood cell distribution width to platelet ratio, Mean platelet volume to platelet ratio, PWR: Platelet to white blood cell ratio, NPR: Neutrophil to platelet ratio, PLR: Platelet to lymphocyte ratio

\section{Ethics}

Ethics Committee Approval: The study was approved by Bezmialem Vakıf University Ethic Committee for Clinical Research (2015/7588).

Peer-review: External and Internal peer-reviewed.

\section{Authorship Contributions}

Concept: Ismail Necati Hakyemez, Design: Ismail Necati Hakyemez, Turan Aslan, Data Collection or Processing: Ismail Necati Hakyemez, Bülent Durdu, Analysis or Interpretation: Sibel Bolukçu Literature Search: Ismail Necati Hakyemez, Bülent Durdu, Writing: Ismail Necati Hakyemez, Turan Aslan.

Conflict of Interest: No conflict of interest was declared by the authors.

Financial Disclosure: The authors declared that this study has received no financial support.

\section{References}

1. Pinzani M. Pathophysiology of Liver Fibrosis. Dig Dis 2015;33:492-497.

2. Castera L, Chan HL, Arrese M, Afdhal N, Bedossa P, FriedrichRust M, Han KH, Pinzani M, European Association for Study of Liver, Asociacion Latinoamericana para el Estudio del Higado. EASL-ALEH Clinical Practice Guidelines: Non-invasive tests for evaluation of liver disease severity and prognosis. J Hepatol 2015;63:237-264.

3. Papatheodoridis G, Buti $M$, Cornberg $M$, Janssen $H L$, Mutimer D, Pol S, Raimondo G, Dusheiko G, Lok A, Marcellin P; European Association For The Study Of The Liver. EASL clinical practice guidelines: Management of chronic hepatitis B virus infection. J Hepatol 2012;57:167-185.

4. Branchi F, Conti CB, Baccarin A, Lampertico P, Conte D, Fraquelli $M$. Non-invasive assessment of liver fibrosis in chronic hepatitis B. World J Gastroenterol 2014;20:14568-14580.

5. Vergara M, Bejarano G, Dalmau B, Gil M, Miquel M, SanchezDelgado J, Casas M, Puig J, Martinez-Bauer E, Dosal A, Lopez M, Moreno L, Valero O, Bella MR, Calvet X. Usefulness of indirect noninvasive methods in predicting progression to cirrhosis in chronic hepatitis C. Eur J Gastroenterol Hepatol 2015;27:826-833.

6. Wan R, Liu H, Wang X, Wan G, Wang X, Zhou G, Jiang $Y$, Sun $F$ Yang $Z$. Noninvasive predictive models of liver fibrosis in patients with chronic hepatitis B. Int J Clin Exp Med 2015:8:961-971.

7. Chen $B, Y e B$, Zhang J, Ying $L$, Chen $Y$. RDW to platelet ratio: a novel noninvasive index for predicting hepatic fibrosis and cirrhosis in chronic hepatitis B. PLoS One 2013;8:68780.

8. Ripoche J. Blood platelets and inflammation: their relationship with liver and digestive diseases. Clin Res Hepatol Gastroenterol 2011;35:353-357.

9. Pradella P, Bonetto S, Turchetto S, Uxa L, Comar C, Zorat F, De Angelis $\mathrm{V}$, Pozzato $\mathrm{G}$. Platelet production and destruction in liver cirrhosis. J Hepatol 2011;54:894-900.

10. Karagoz E, Ulcay A, Tanoglu A, Kara M, Turhan V, Erdem $H$, Oncul O, Gorenek L. Clinical usefulness of mean platelet volume and red blood cell distribution width to platelet ratio for predicting the severity of hepatic fibrosis in chronic hepatitis $B$ virus patients. Eur J Gastroenterol Hepatol 2014;26:1320-1324.

11. Zhang S, Cui YL, Diao MY, Chen DC, Lin ZF. Use of Platelet Indices for Determining Illness Severity and Predicting Prognosis in Critically III Patients. Chin Med J 2015;128:20122018.

12. Golcuk Y, Golcuk B, Bilge A, Irik M, Dikmen O. Combination of mean platelet volume and the CURB-65 score better 
predicts 28-day mortality in patients with community-acquired pneumonia. Am J Emerg Med 2015;33:648-652.

13. Fluss R, Faraggi D, Reiser B. Estimation of the Youden Index and its associated cutoff point. Biom J 2005;47:458-472.

14. Allen LA, Felker GM, Mehra MR, Chiong JR, Dunlap SH, Ghali JK, Lenihan DJ, Oren RM, Wagoner LE, Schwartz TA, Adams KF Jr. Validation and potential mechanisms of red cell distribution width as a prognostic marker in heart failure. J Card Fail 2010;16:230-238.

15. Knight $V$, Tchongue J, Lourensz $D$, Tipping P, Sievert W. Protease-activated receptor 2 promotes experimental liver fibrosis in mice and activates human hepatic stellate cells. Hepatology 2012;55:879-887.

16. McHutchison JG, Manns MP, Longo DL. Definition and management of anemia in patients infected with hepatitis $C$ virus. Liver Int 2006;26:389-398.

17. Lou Y, Wang M, Mao W. Clinical usefulness of measuring red blood cell distribution width in patients with hepatitis B. PloS One 2012;7:e37644.

18. Xu WS, Qiu XM, Ou QS, Liu C, Lin JP, Chen HJ, Lin S, Wang $\mathrm{WH}$, Lin SR, Chen J. Red blood cell distribution width levels correlate with liver fibrosis and inflammation: a noninvasive serum marker panel to predict the severity of fibrosis and inflammation in patients with hepatitis B. Medicine (Baltimore) 2015;94:e612.

19. Aiolfi R, Sitia G. Chronic hepatitis B: role of anti-platelet therapy in inflammation control. Cell Mol Immunol 2015;12:264-268.

20. Xiao G, Yang J, Yan L. Comparison of diagnostic accuracy of aspartate aminotransferase to platelet ratio index and fibrosis-4 index for detecting liver fibrosis in adult patients with chronic hepatitis B virus infection: a systemic review and meta-analysis. Hepatology 2015;61:292-302.

21. Cengiz M, Ozenirler S. Comparative diagnostic accuracy of red cell distribution width-to-platelet ratio versus noninvasive fibrosis scores for the diagnosis of liver fibrosis in biopsy-proven nonalcoholic fatty liver disease. Eur J Gastroenterol Hepatol 2015;27:1293-1299.

22. Lee HW, Kang W, Kim BK, Kim SU, Park JY, Kim do Y, Ahn SH, Park YN, Han KH. Red cell volume distribution width-to-platelet ratio in assessment of liver fibrosis in patients with chronic hepatitis B. Liver Int 2016;36:24-30.

23. Taefi A, Huang CC, Kolli K, Ebrahimi S, Patel M. Red cell distribution width to platelet ratio, a useful indicator of liver fibrosis in chronic hepatitis patients. Hepatol Int 2015;9:454460.

24. Farias MG, Schunck EG, Dal Bó S, de Castro SM. Definition of reference ranges for the platelet distribution width (PDW): a local need. Clin Chem Lab Med 2010;48:255-257.

25. Purnak T, Olmez S, Torun S, Efe C, Sayilir A, Ozaslan E, Tenlik I, Kalkan IH, Beyazit $Y$, Yuksel O. Mean platelet volume is increased in chronic hepatitis $C$ patients with advanced fibrosis. Clin Res Hepatol Gastroenterol 2013;37:41-46.

26. Gasparyan AY, Ayvazyan L, Mikhailidis DP, Kitas GD. Mean platelet volume: a link between thrombosis and inflammation? Curr Pharm Des 2011;17:47-58.

27. Kadan M, Karabacak K, Kaya E, Arslan G, Erol G, Doğancı S, Yıldırım V, Bolcal C, Demirkılıç U. Platelet indices may be correlated with severity of vasospastic disorders. Med Sci Monit Basic Res 2015;21:63-67.

28. Ates S, Oksuz H, Dogu B, Bozkus F, Ucmak H, Yanıt F. Can mean platelet volume and mean platelet volume/platelet count ratio be used as a diagnostic marker for sepsis and systemic inflammatory response syndrome? Saudi Med J 2015;36:11861190.

29. Abdel-Razik A, Mousa N, Shabana W, Refaey M, EIMahdy Y, Elhelaly R, Elzehery R, Zalata K, Arafa M, Elbaz S, Hafez M, Awad M. A novel model using mean platelet volume and neutrophil to lymphocyte ratio as a marker of nonalcoholic steatohepatitis in NAFLD patients: multicentric study. Eur J Gastroenterol Hepatol 2016;28:e1-9.

30. Cho SY, Yang JJ, You E, Kim BH, Shim J, Lee HJ, Lee WI, Suh JT, Park TS. Mean platelet volume/platelet count ratio in hepatocellular carcinoma. Platelets 2013;24:375-377.

31. Lai Q, Castro Santa E, Rico Juri JM, Pinheiro RS, Lerut J. Neutrophil and platelet-to-lymphocyte ratio as new predictors of dropout and recurrence after liver transplantation for hepatocellular cancer. Transpl Int 2014;27:32-41.

32. Menezes BM, Amorim FF, Santana AR, Soares FB, Araújo FVB, de Carvalho JR, de Araujo MPB, de Carvalho Santos LC, Rocha PHG, de Souza JL, Gomes MG, Junior PNF, Amorim APP, Biondi RS, Ribeiro RAB. Platelet/leukocyte ratio as a predictor of mortality in patients with sepsis. Critical Care 2013;17 (Suppl 4):P52.

33. De Ferrari GM, Somaschini A, Cornara S, Pepe A, Pavesi C, Camporotondo R, Repetto A, Potenza A, Gnecchi M, Ferrario M. Neutrophil to platelet ratio: a novel prognostic biomarker in STEMI patients undergoing primary percutaneous coronary intervention. J Am Coll Cardiol 2015;65.

34. Ates I, Bulut M, Ozkayar N, Dede F. Association between high platelet indices and proteinuria in patients with hypertension. Ann Lab Med 2015;35:630-634.

35. Tsai MH, Lin KH, Lin KT, Hung CM, Cheng HS, Tyan YC, Huang HW, Sanno-Duanda B, Yang MH, Yuan SS, Chu PY. Predictors for Early Identification of Hepatitis C Virus Infection Biomed Res Int 2015;2015:429290. 